\title{
Use of the Pro-Seal LMA facilitates percutaneous dilatational tracheostomy
}

\author{
[L'utilisation du masque laryngé Pro-Seal facilite la trachéotomie dilatatrice percutanée]
}

Rachael M. Craven FrCA, Stephen R. Laver MB CHB, Tim M. Cook FRCA, Jerry P. Nolan FRCA

Purpose: To study the feasibility of using the Pro-Seal laryngeal mask airway (LMA) for airway maintenance during bronchoscopic guided percutaneous tracheostomy.

Methods: Observational study of 23 patients in an I I-bed general intensive care unit. The patient's tracheal tube was exchanged for a Pro-Seal LMA before undertaking percutaneous tracheostomy.

Results: Inspiratory pressure and tidal volumes achieved during the procedure were recorded. The median peak inspiratory pressure was 25 (standard deviation 4.2) $\mathrm{cm} \mathrm{H}_{2} \mathrm{O}$. There was no loss of tidal volume in I I patients, a loss of less than $100 \mathrm{~mL} \cdot$ breath $^{-1}$ in II, and loss of more than $100 \mathrm{~mL}$ in one. A Pro-Seal LMA successfully maintained the airway and allowed adequate ventilation during percutaneous tracheostomy in all 23 patients. In all patients bronchoscopy through the Pro-Seal LMA provided a clear view of the cords and trachea and there was no laryngeal or tracheal soiling at any stage of the procedure.

Conclusion: The Pro-Seal LMA provides a reliable airway and allows effective ventilation during percutaneous tracheostomy. The passage of a fibrescope through the Pro-Seal LMA and glottis is easy and provides a clear view of the upper trachea.

Objectif : Étudier la faisabilité de l'utilisation du masque laryngé (ML) Pro-Seal pour maintenir la perméabilité des voies aériennes pendant la trachéotomie percutanée à guidage bronchoscopique.

Méthode : L'étude par observation comportait 23 patients d'une unité de soins intensifs généraux. Un ML Pro-Seal a remplacé le tube trachéal avant la trachéotomie percutanée.

Résultats : La pression inspiratoire et les volumes courants obtenus pendant l'intervention ont été notés. La moyenne de la pression inspiratoire maximale a été de $25 \mathrm{~cm} \mathrm{H}_{2} \mathrm{O}$ (écart type de 4,2). II n'y a pas eu de perte de volume courant chez I I patients. Une perte de moins de $100 \mathrm{~mL} \cdot$ respiration ${ }^{-1}$ a été notée chez I I patients et une perte de plus de $100 \mathrm{~mL}$ chez un patient. Le ML Pro-Seal a maintenu avec succès la perméabilité des voies aériennes et permis une ventilation adéquate pendant la trachéotomie percutanée chez les 23 patients.
Chez tous, la bronchoscopie réalisée en passant par le ML Pro-Seal a offert une vision claire des cordes vocales et de la trachée, sans contamination laryngée ou trachéale tout au long de l'intervention.

Conclusion : Le ML Pro-Seal assure la perméabilité des voies aériennes et permet une ventilation efficace pendant la trachéotomie percutanée. Le passage du fibroscope par le ML Pro-Seal et la glotte est facile et permet de visualiser clairement la trachée supérieure.

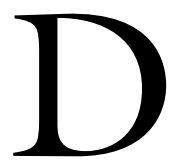

URING percutaneous dilatational tracheostomy (PDT) the patient's airway is usually maintained with a tracheal tube, which is pulled back until the cuff is lying across the vocal cords. ${ }^{1,2}$ In this position, the tracheal tube is unstable and may become dislodged with loss of the airway and risk of aspiration. Most commonly, bronchoscopy is undertaken during the procedure to aid correct placement of the guidewire. ${ }^{3}$ An assistant is generally required to stabilize the tracheal tube while fibreoptic examination is performed and, as the glottis is not seen, it can be very difficult to determine the level at which the cannula enters the trachea. The tip of the tracheal tube may still lie low enough within the trachea to risk cuff puncture or tube transfixion by the needle. Use of the classic laryngeal mask airway $(\mathrm{LMA})^{4-6}$ or the intubating $\mathrm{LMA}^{7}$ during PDT circumvents many of these problems. However, patients requiring PDT often have poorly compliant lungs requiring high inflation pressures. Gas leak from between the LMA and glottis increases as inspiratory airway pressure rises, particularly above $20 \mathrm{~cm} \mathrm{H}_{2} \mathrm{O}$. This leads to a risk of hypoventilation in patients with poorly compliant lungs.

The Pro-Seal LMA (Intavent Orthofix, Maidenhead, United Kingdom) incorporates a drain tube placed lat-

From the Department of Anaesthesia and Intensive Care Medicine, Royal United Hospital, Bath, United Kingdom.

Address correspondence to: Dr. Jerry P. Nolan, Consultant in Anaesthesia and Intensive Care Medicine, Royal United Hospital, Combe

Park Bath BAl 3NG, United Kingdom. Phone: +44-1225-825057; Fax: +44-1225-825061; E-mail: jerry.nolan@ruh-bath.swest.nhs.uk

Disclosure statement: TM Cook has received a small honorarium for a lecture delivered on behalf of Intavent.

Accepted for publication December 23, 2003.

Revision accepted April 30, 2003. 
eral to the airway tube and ending at the mask tip. ${ }^{9}$ The second tube aids correct placement of the mask; if the mask is placed correctly, with its tip against the upper esophageal sphincter, no air leak is heard. This tube allows passage of a gastric tube and will vent air or fluid from the upper esophagus. The Proseal LMA provides a better laryngeal seal than the classic LMA because of a deeper mask bowl and extension of the cuff over the posterior aspect of the bowl. ${ }^{10}$ The aim of this observational study was to evaluate the efficacy of the Pro-Seal LMA during PDT under bronchoscopic guidance.

\section{Methods}

Patients

We prospectively studied 23 consecutive patients in the intensive care unit who required elective tracheostomy. The lungs of all patients were ventilated with a Draeger Evita 4 ventilator (Draeger Limited, Hemel Hempstead, UK) using a bi-level positive airway pressure mode.

\section{Technique}

All patients were sedated with propofol 200 to 300 $\mathrm{mg} \cdot \mathrm{hr}^{-1}$ and alfentanil $\mathrm{l}$ to $3 \mathrm{mg} \cdot \mathrm{hr}^{-1}$. Paralysis was achieved with atracurium $0.5 \mathrm{mg} \cdot \mathrm{kg}^{-1}$ or vecuronium $0.1 \mathrm{mg} \cdot \mathrm{kg}^{-1}$. The inspired oxygen concentration was increased to $100 \%$. The pharynx was suctioned under direct vision. The nasogastric tube was aspirated and left in situ throughout the procedure. The patient was positioned with the neck extended and a pillow placed under the shoulders. The tracheal tube was removed, a Pro-Seal LMA inserted (size 4 for females and size 5 for males), and the cuff inflated. Correct positioning of the Pro-Seal LMA was confirmed by the achievement of an adequate expired tidal volume with minimal leak from the drain tube. The patient's neck was cleaned and draped. The cricoid cartilage was identified and the skin over the space between the first and second tracheal rings was infiltrated with $2 \%$ lidocaine. A bronchoscope was passed through a swivel connector on the Pro-Seal. The tip of the bronchoscope was positioned just below the glottis and correct position of the tracheal puncture was confirmed in relation to both the midline and the level. A Cook "Blue Rhino" PDT kit (Cook Critical Care, Cook UK Ltd, Letchworth, Herts SG6 ILN, UK) was used in all cases. The airway pressure and tidal volumes were recorded during insertion of the dilator and the presence of any gas leak was noted.

\section{Results}

Individual patient data are displayed in the Appendix (available as "additional material" at www.cja-jca.org). The Pro-Seal LMA successfully maintained the airway and allowed adequate ventilation during percutaneous tracheostomy in all 23 patients. In two patients more than one attempt was required to insert the device. In one male patient the size 5 Pro-Seal LMA was changed to a size 4 to provide a better seal with the larynx. The median peak inspiratory pressure was 25 $\mathrm{cm} \mathrm{H}_{2} \mathrm{O}\left(\mathrm{SD} 4.2 \mathrm{~cm} \mathrm{H}_{2} \mathrm{O}\right)$ and the median expired tidal volume was $450 \mathrm{~mL}$ (SD $93 \mathrm{~mL}$ ). There was no loss of tidal volume in 11 patients, minimal loss (less than $100 \mathrm{~mL} \cdot$ breath $\left.^{-1}\right)$ in 11 , and moderate loss $(200$ $\mathrm{mL}$ ) in one. The lowest $\mathrm{SpO}_{2}$ recorded during the procedure was $84 \%$ and this occurred in a patient in whom the $\mathrm{SpO}_{2}$ was $92 \%$ at the outset. The median lowest recorded $\mathrm{SpO}_{2}$ was $95 \%$.

Gastric fluid appeared in the drain tube during the procedure in two patients. In one of these cases this fluid was approximately $50 \mathrm{~mL}$ of enteral feeding solution (despite aspiration of the stomach before the procedure), and in the other it appeared to be bile. In both these cases, the fluid was vented effectively up the drain tube. In all patients bronchoscopy through the Pro-Seal LMA provided a clear view of the cords and trachea and there was no laryngeal or tracheal soiling at any stage of the procedure.

\section{Discussion}

Use of any form of LMA during PDT has the potential to overcome many of the problems associated with the procedure ${ }^{4-7}$ In particular, the airway device is in a stable position and lies outside the larynx minimizing the risks of dislodgement, glottic damage and tube transfixion. Bronchoscopic examination may be performed from the laryngeal inlet allowing accurate identification of the laryngeal rings and avoiding risk of damage to the bronchoscope. In comparison with the classic LMA, the absence of aperture bars on the Pro-Seal LMA improves bronchoscopic access to the glottis during the procedure. In the presence of poor lung compliance and high airway pressures, the ProSeal LMA will provide more effective ventilation than the classic $\operatorname{LMA}^{9,10}$ and we were able to provide adequate ventilation in all 23 patients despite inspiratory airway pressures of up to $35 \mathrm{~cm} \mathrm{H}_{2} \mathrm{O}$.

Provisional work in cadavers, supported by some case reports, suggests that the drain tube of the Pro-Seal LMA will allow regurgitated matter to bypass the larynx. ${ }^{11-13}$ This was witnessed in two of our patients and, in all patients, laryngeal/tracheal soiling was absent.

The potential for airway loss during changeover of the airway device is a theoretical limitation of the technique. But, accidental extubation during PDT may also cause loss of the airway as well as the risk of aspiration. 
In conclusion, our experience suggests that the ProSeal LMA can be used to safely maintain the airway during PDT. Use of the Pro-Seal LMA during bronchoscopic guided PDT facilitates a good view of the upper trachea and avoids the possibility of accidental extubation or puncture of the tracheal tube cuff.

\section{References}

1 Ciaglia P, Firsching R, Syniec C. Elective percutaneous dilatational tracheostomy. A new simple bedside procedure; preliminary report. Chest 1985; 87: 715-9.

2 Mercer M, Manara AR. Percutaneous tracheostomy in the intensive care unit. Curr Opin Anaesthesiol 1999; 12: 701-6.

3 Reilly PM, Shapiro MB, Malcynski JT. Percutaneous dilatational tracheostomy under the microscope: justification for intra-procedural bronchoscopy? (Editorial). Intensive Care Med 1999; 25: 3-4.

4 Dexter TJ. The laryngeal mask airway: a method to improve visualisation of the trachea and larynx during fibreoptic assisted percutaneous tracheostomy. Anaesth Intensive Care 1994; 22: 35-9.

5 Zuleika M, Jacobs S, Mphanza T, Brobi F. The use of the laryngeal mask airway in suitable ICU patients undergoing percutaneous dilational tracheostomy (Letter). Intensive Care Med 1997; 23: 129-30.

6 Dosemeci L, Yilmaz M, Gurpinar F, Ramazanoglu A. The use of the laryngeal mask airway as an alternative to the endotracheal tube during percutaneous dilatational tracheostomy. Intensive Care Med 2002; 28: 63-7.

7 Veghese C, Rangasami J, Kapila A, Parke T. Airway control during percutaneous dilatational tracheostomy: pilot study with the intubating laryngeal mask airway. Br J Anaesth 1998; 81: 608-9.

8 Devitt JH, Wenstone R, Noel AG, O'Donnell MP. The laryngeal mask airway and positive-pressure ventilation. Anesthesiology 1994; 80: 550-5.

9 Brain AIJ, Verghese C, Strube PJ. The LMA 'Pro-Seal' a laryngeal mask with an oesophageal vent. $\mathrm{Br} \mathrm{J}$ Anaesth 2000; 84: 650-4.

10 Cook TM, Nolan JP, Verghese C, et al. A randomized crossover comparison of the ProSeal with the classic laryngeal mask airway in unparalysed anaesthetized patients. Br J Anaesth 2002; 88: 527-33.

11 Keller C, Brimacombe J, Kleinsasser A, Loekinger A. Does the ProSeal laryngeal mask airway prevent aspiration of regurgitated fluid? Anesth Analg 2000; 91: 1017-20.

12 Evans NR, Llewellyn RL, Gardner SV, James MF. Aspiration prevented by the ProSeal ${ }^{\mathrm{TM}}$ laryngeal mask airway: a case report. Can J Anesth 2002; 49: 413-6.

13 Mark DA. Protection from aspiration with the LMAProSeal ${ }^{\mathrm{TM}}$ after vomiting: a case report. Can J Anesth 2003; 50: 78-80. 